\title{
Analysis on Tax Collection and Management of Digital Economy
}

\author{
Chun-xiao Zhu ${ }^{1, a}$ \\ ${ }^{1}$ Financial department Linyi University Linyi, Shandong
}

\begin{abstract}
Digital economy is a new form of economic and social development based on a new generation of information technology. The rapid development of cloud computing, Internet of Things, big data, 5G and other information technologies and infrastructure have promoted the rapid development of China's digital economy. Due to the digitization of goods and services and the intangibility of assets in the digital economy model, it has also brought opportunities and challenges to the traditional tax collection and management model. This paper introduces the current scale of China's digital economy and the impact of the digital economy on China's tax collection and administration, clarifies the opportunities and challenges facing China's current tax collection and administration model, and combines the case analysis of China's digital economy tax collection and administration to give corresponding countermeasures and suggestions.
\end{abstract}

\section{The need to strengthen tax collection and management of the digital economy}

At the end of 2019, China still maintained its status as the world's second largest digital economy, with a scale of 35.8 trillion, accounting for as high as $36.2 \%$ of GDP. In addition, the scale of China's cloud computing industry has exceeded 100 billion yuan in 2019, and the Internet of Things industry has reached 1.49 trillion yuan. The novel coronavirus has forced everyone to "cloud office" and "cloud class", which has led to a surge in applications such as cloud computing and the Internet of Things. Some investment institutions predict that the number of Internet medical users will reach 59 million in 2020, with a penetration rate of $7.9 \%$, and market size 700 billion yuan. The scale of China's Internet of Things industry will exceed 2 trillion yuan in 2020. As of March 2020, the number of Chinese Internet users was 904 million, and the Internet penetration rate reached $64.5 \%$, an increase of 4.9 percentage points from the end of 2018 .

The proportion of China's digital economic income in national income is already very high, and its proportion is still rising year by year. Fig. 1 shows the scale of China's digital economy and its proportion in GDP from 2014 to 2019. At the same time, the large number of Internet users in China has brought great potential to the development of digital economy. In today's world of rapid technological revolution and industrial transformation, the digital economy has profoundly changed the life style of human production. In the foreseeable future, the digital economy will inevitably involve more and more fields and play a pivotal role in the life of the national economy. The rapid development of the digital economy, especially the rapid rise of various new business models, not only requires the establishment of new trade cooperation mechanisms and the formation of new trade rules, but also brings new challenges to the tax management. However, due to the concealment and virtualization of transaction subjects, tax authorities cannot obtain taxpayers' tax-related information accurately and comprehensively. Moreover, in the current platform economic environment, largescale transactions are replaced by many fragmented exchanges. The cost of tracking the transaction process is high, resulting in a large amount of tax losses. For example, many e-commerce platforms, online games, online celebrity live broadcasts or micro-businesses will more or less involve tax issues. Some scholars estimate that based on the data published on Ali's official website in 2018, the loss of personal income tax and value-added tax will exceed 100 billion. Therefore, in this context, it is urgent to strengthen the collection and management of the digital economy.

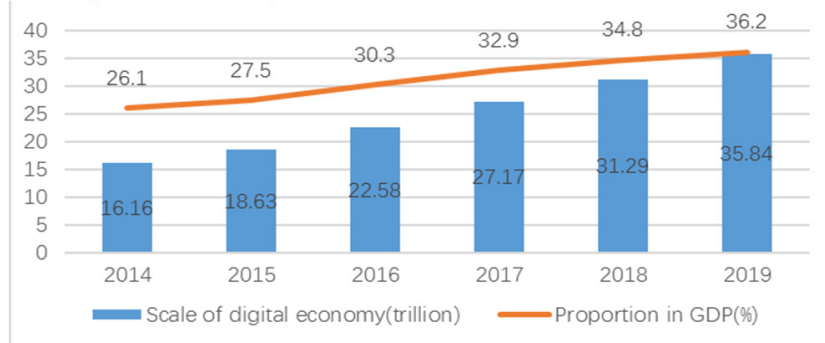

Fig1. The scale of China's digital economy and its proportion in GDP from 2014 to 2019 


\section{Opportunities and challenges of tax collection and management in digital economy}

\subsection{Opportunities for tax collection and administration}

Firstly, the expansion of the tax base is one of the opportunities brought by the digital economy. Due to the development of the new generation of information technology, many companies have enjoyed the dividends brought by the digital economy. The transaction costs of companies have dropped significantly, and the scope of business coverage is very wide. As a result, the number and scale of corporate transactions have increased more than before, thereby expanding the tax base.

Secondly, the development of the digital economy has brought many advanced technological achievements. While enterprises enjoy these achievements, they have also improved the efficiency of tax collection and administration departments. In recent years, the taxation department has introduced enterprise electronic invoices, established a tax credit rating system, and applied blockchain technology to new collection and management methods which have greatly improved the efficiency of tax collection and management, saved time and reduced the tax authorities work pressure.

Thirdly, this is also a major opportunity for China to participate in and lead digital economy taxation supervision and international cooperation. We should seize this opportunity to take the initiative in formulating international taxation rules, actively participate in the formulation of international taxation rules, and increase China's voice and influence in the world. At the same time, we should improve China's international taxation legal system and adjust taxation rules as soon as possible. On the premise of not affecting the development of the digital economy and increasing the tax burden of enterprises, China's tax interests are effectively protected from infringement.

\subsection{Challenges for tax collection and management}

\subsubsection{Difficulty in determining the three elements of} Taxation: The three elements of taxation refer to the taxpayer, the tax object and the tax rate used. The current tax collection and management system in China is based on the traditional economic situation, the three elements of traditional economic forms of taxation are easy to distinguish, under the digital economy, the virtualization of goods and the concealment of buyers make it difficult to determine the taxpayer, tax object and tax rate.[1] For example, for some new industries, there are many uncertainties in the tax collection and management of these industries, and the transaction is difficult to trace and determine, which has set many obstacles for the tax authorities' collection and management.
2.2.2 Challenge to the "permanent establishment" rule: In the traditional economy, based on the reason why tax authorities can more clearly identify taxpayers in transaction activities, tax authorities can levy taxes on taxpayers through various physical presences such as the location of real estate and the location of the actual management agency of the enterprise. Due to the virtual characteristics of the digital economy, many companies do not need physical office space, and even the entire process of commodity transactions does not have a physical presence.[2,3] For example, in cross-border ecommerce activities, the support of "physical existence" is not needed from negotiation, order to delivery. In the digital economy, companies can easily cross national borders, realize the global allocation of resources, and reduce their dependence on institutional locations. For example, in the application store of Huawei mobile phones, people all over the world can buy Huawei mobile phones, and can purchase and download applications from the application store. But unlike a real shopping mall, the application mall is not a real business place, it is just a virtual platform composed of some programming, so it cannot be regarded as a permanent establishment.

\subsection{Difficulty in obtaining accurate tax related information}

In the digital economy, companies rely heavily on data, and data is an important asset and source of profits for companies. Determining its value is also a prerequisite for taxation, but the value of data is difficult to determine due to its own characteristics. In addition, the value of the data after analysis and processing by professionals is difficult to determine the value-added part of the original data, which makes it difficult to determine the price and cost, which leads to the digital economy facing challenges in taxation. [4] In terms of tax-related information, taxpayers will find ways to avoid tax when they understand their transaction information. However, in the digital economy, due to the lack of a sound information system, the tax agency, as a third party, cannot obtain timely and accurate tax-related information. Although there have been more and more third-party regulatory agencies for tax-related information, and they have played an important role, as more and more companies and individuals participate in the digital economy, if information is not symmetrical, there will still be a lot of tax losses, and it is difficult to effectively meet the requirements of the modernization of tax governance under the new situation.

\subsection{International double taxation}

The development of the digital economy also poses severe challenges to the application of various countries' consumption taxation systems (that is, general commodity and labor tax systems such as value-added tax and business tax). Although all countries implement a single territorial taxation principle in terms of consumption taxation. However, the specific manifestations are different from the origin taxation 
principle (also known as the destination taxation principle or the destination taxation principle). For the consumption taxation of cross-border online sales of digital products or services, if the applicable territorial taxation principles of the relevant countries are different, it will also lead to international double taxation or double non-taxation of the turnover of such cross-border sales transactions.[5] For example, Singapore adopts the principle of levying tax at the location of the service provider for the confirmation of the place where the value-added tax for the service is provided, while Australia adopts the principle of levying the tax at the actual consumption place of the service. The difference in taxation principles between the two countries may be Lead to double taxation of the same international service. From the perspective of multilateral cooperation mechanisms, in addition to the larger international tax cooperation platforms such as OECD and the United Nations, there are also global or regional organizations such as the European Union and the World Bank, all of which have professional experience in formulating international tax systems. China should strengthen cooperation with these platforms and organizations, and continue to increase the depth and breadth of China's participation in digital economy taxation. From the perspective of bilateral cooperation mechanisms, China has signed hundreds of bilateral tax treaties, but the applicability of these tax treaties to the digital economy has declined significantly. China should cooperate with relevant countries to revise and update bilateral tax treaties to better coordinate the bilateral digital economy and international tax relations.

\section{Analysis of typical cases}

In May 2020, many online store merchants received tax reimbursement text messages from the tax bureau, which made the online store merchants of Tmall, Taobao and JD.com who are sprinting for the "618-year big promotion" completely panicked. The tax bureau's text message read: "Our bureau uses big data to analyze and compare and find that the sales income reported by your unit from 2017-0101 to 2019-12-31 is quite different from the sales income of the e-commerce platform. According to the provisions of the "Interim Regulations of the People's Republic of China on Value-Added Tax" and "The Enterprise Income Tax Law of the People's Republic of China", they should take their units into account the actual situation, conduct a comprehensive self-examination and self-correction, modify relevant reports, pay taxes and late fees. Through Alipay's shopping process in Taobao, as shown in Fig. 2.It is reported that the first batch of companies to be notified is to pay according to Alipay's total income. In fact, the difference between the sales revenue declared by the company and the sales revenue amount calculated by the ecommerce platform is the transaction amount that the company relies on by scalping, and the income obtained by the enterprise by scalping cannot even make up for the tax. The principle of scalping is that the merchant contacts the customer to buy things in the store. After the customer pays the money, the merchant reclaims the money to the customer, and the customer purchases are not actually delivered, usually empty packages or small items.

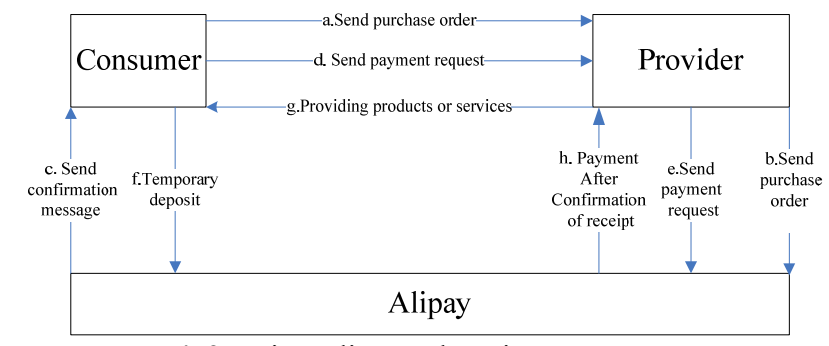

Fig2. Using Alipay's shopping process

Some dishonest behaviors, such as non-tax payment and scalping, have become an industry cancer. This not only violates the fairness principle of physical and network operations, but also disrupts the order of the market economy and makes market integrity disappear. However, in the past, due to the incomplete openness between platform data and tax authorities, many online shops took advantage of this to "evade tax." Not only online stores, but also many e-commerce live broadcast platforms, fictitious their transaction amount, treat the fictitious transaction amount as taxable income, declare tax, calculate and pay VAT and corporate income tax in full, and do not issue value-added transactions for such transactions. Prior to this, these transaction data were concealed, and the tax bureau could not get it, leading many businesses to take advantage of the loopholes. After the State Administration of Taxation established the Tax Big Data and Risk Administration in December 2019, the Tax Administration has strengthened cooperation with many e-commerce platforms. We are in an era of big data. As long as the tax bureau has big data, these tax evasion under the digital economy will be invisible.

\section{Countermeasures and suggestions}

\subsection{Revise the rules for the recognition of permanent establishments}

Due to the strong virtuality, concealment and liquidity of the subjects, participants and transactions of the digital economy, the enterprises relying on the development of the digital economy no longer rely on the offline business places. Therefore, the criteria for determining a permanent establishment should also keep pace with the times. The perfect legal system of source country, smooth operation of payment system, strengthening of intellectual property protection and improvement of digital environment will also benefit the development of digital enterprises. The complete legal system of the source country, the smooth operation of the payment system, the strengthening of intellectual property protection, and the improvement of the digital environment will also benefit the development of digital enterprises. [6] Therefore, China needs to change the concept of permanent establishment by designing new rules. In the income tax system and tax collection and management legislation, consideration can be given to increase the recognition of virtual permanent establishments or to modify the exception clauses of permanent establishments. As well as those digital 
enterprises that constitute a significant presence, China also has the right to tax them.

\subsection{Promote a new data-centric tax collection and management model}

Due to the digitalization of transactions, the key to improving the level of tax collection and management is to vigorously develop "data-controlled taxation" and promote the electronicization of tax-related information so that taxation affairs can be processed electronically throughout the process. [7] To quote the words of Alibaba Academician Wang Jian, when the Internet becomes an infrastructure, when data becomes the most important means of production, when computing becomes a public service and the core competitiveness of enterprise development, a new era has arrived, and that is the era of computing economy. The new infrastructure proposed by the two sessions this year includes communication network infrastructure represented by $5 \mathrm{G}$, Internet of things, Industrial Internet, and satellite Internet, and new technical infrastructure represented by artificial intelligence, cloud computing, and block chain. The computing power infrastructure represented by the center and the intelligent computing center have brought new inspiration to tax collection and management. Promote the rapid integration of these new technologies with China's tax collection and management, improve tax collection and management efficiency, and reduce tax costs. We will promote cooperation between tax authorities and big data centers, as shown in Fig. 3, do a good job of monitoring tax sources, cooperate with Internet platforms, and clarify the platform's obligations and responsibilities for information sharing and withholding. We will set up a supervision mechanism, an incentive mechanism and a punishment mechanism in the cooperation mechanism, actively promote electronic invoices, promote the optimization and upgrading of the tax handling business of the platform economy, and save the cost of tax handling.[8]

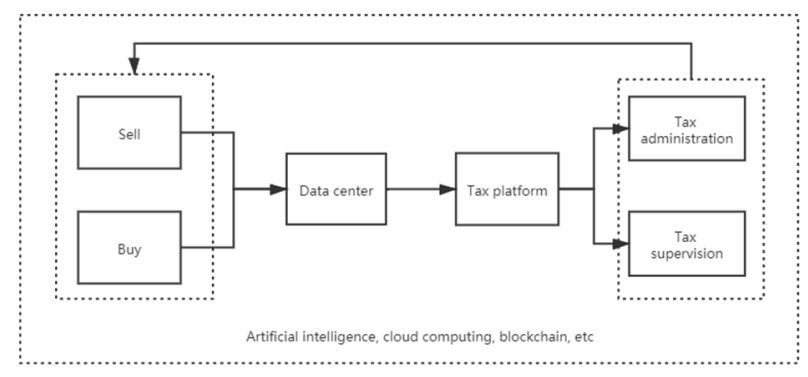

Fig3. A new data-centric tax collection and management model

\subsection{Strengthen international value-added tax coordination}

For cross-border value-added tax collection, the application of the destination principle is also the general trend of the international community. The OECD's "International Value-Added Tax/Goods and Services Tax Guidelines" issued in 2017 also confirmed the importance of the destination principle in solving the problem of crossborder digital services and intangible value-added tax collection. As of the end of 2018, more than 50 countries have levied value-added tax on intangible products and services provided by overseas suppliers to domestic users, and most of them have followed the International ValueAdded Tax Guidelines issued by the OECD. For services such as e-books, advertisements, games, music, audiovisual, software and other services provided by overseas service providers to domestic customers based on the Internet, the European Union, Japan, South Korea, etc. have clearly stipulated that the value-added needs to be levied in the market country based on the principle of consumption tax. The European Union and Japan stipulate that in the case of $\mathrm{B} 2 \mathrm{~B}$, a reverse collection mechanism is adopted, and the domestic enterprise receiving the service is the subject of VAT tax; in the case of business-to-customer (B2C), the overseas service provider is registered and paid in the country VAT. South Korea and other countries do not distinguish between the identity of the buyer, and all overseas service providers are required to register and pay VAT in their home country. China's current value-added tax rules have better reflect the destination principle than before, but they should still be clear in the form of legislation. Moreover, for digital services and goods, the applicable standards of the destination principle should be more detailed. For example, the consumer's residential address, Internet Protocol address (IP address), household registration address or the address provided by payment information when purchasing goods or services are used as the criteria for identification.

\subsection{Increase the training of tax talents}

With the rapid development of information technology, China's need for compound tax collection and management talents is becoming more and more urgent. China not only needs tax talents who understand tax knowledge, but also computer talents who understand computer languages. The strengthening of international taxation cooperation and the planning and practice of international taxation practices require China to increase the training of talents. In addition to cultivating interdisciplinary talents, China needs to integrate various resources, strengthen exchanges, set up a talent incentive mechanism, and encourage talents to cultivate their own abilities in various aspects, not limited to a certain field. In this way, while improving the overall quality of the tax collection team, it can also ensure the synchronous development of tax collection and information technology.

\section{Conclusion}

With the continuous expansion of the scale of the digital economy, new economic models are constantly emerging. The tax management activities of the digital economy should not only ensure tax fairness, but also avoid excessive tax intervention in the normal operation of the digital economy market. In addition, tax collection and management activities should also accelerate the pace of reform, strive for common development with the digital 
economy, overcome technical shortcomings, build information sharing platform, strengthen national cooperation, and promote the healthy development of digital economy and China's tax collection and management.

\section{Acknowledgment}

This paper has been supported by Shandong Education Accounting Association 2019 Scientific Research Project under Grant No. sdjk2019155.

\section{References}

1. Jin Zhidan. Standard of permanent establishment in digital economy $[\mathrm{J}]$. Modern economic information, 2020 (07): $127+129$.

2. Yixin Liao. On the concept of permanent establishment applicable to the e-commerce environment [J]. Journal of Xiamen University (Philosophy and Social Sciences Edition), 2003(04): $13-21+62$.

3. Jiang Yan. Thoughts on the impact of digital economy on taxation [J]. Enterprise Technology and Development, 2020(05): 153-154.

4. Wang Sudan. Challenges and Countermeasures brought by digital economy to international tax jurisdiction system [J]. Accounting study, 2019, 000 (001): 7-8.

5. Jia Kai. Where is the future vision of "digital tax"? [N]. 21st Century Business Herald, 2020-04-13(004).

6. Li Rui, Li Shuijun. Digital Economy: How China's Taxation System Responds[J]. Taxation Research, 2020(03):91-98.

7. Li P . Research on Influence of Digital Economy on Taxation[C]// International Conference on Humanities Science. 2017.

8. Zhou Keqing, Li Xia. Taxation governance system innovation under platform economy[J]. Taxation Research, 2018(12):73-77. 